\title{
PENGUATAN TATAKELOLA UKM TENUN IKAT TROSO
}

\author{
Hadi Ismanto \\ Fakultas Ekonomi dan Bisnis, Universitas Islam Nahdlatul Ulama Jepara \\ email: hadifeb@unisnu.ac.id
}

Key word:

Weaving, Bind, SME, Craft

\section{Kata Kunci}

Tenun, Ikat, UKM,

Kerajinan

\begin{abstract}
Troso tie is a Jepara weaving craft from Troso Village. This fabric is weaved from strands or lint threads that previously tied to form a particular motif and immersed in a natural dye. Until now Tenun Troso has grown into a home industry that supports the economy with a broader market in various regions in Indonesia, Malaysia and Brunei Darussalam. In running its business the craftsmen pay less attention to management aspect and also consistency aspect of product quality. Problems that exist in partner SMEs, among others; 1) Having difficulty in recruiting employees and technology that still rely on human strength; 2) Do not have a good financial administration system yet. From these problems then the solution offered as follows: 1) Modify Non-Engine Weaving Machine (ATBM) into a semi-machine loom (ATSM); 2) Developing the Financial Administration System. The solutions offered have a purpose: 1) Product Quality Improvement; 2) Minimizing the Dependency of Skilled Weaving and For Increasing Productivity of the Produce Cloth; 3) Facilitating the Craftsman in Preparing and Controlling the Work and Giving Ease In Taking Decision
\end{abstract}

\begin{abstract}
Abstrak
Tenun Troso merupakan kriya tenun Jepara dari Desa Troso. Kain ini ditenun dari helaian benang pakan atau benang lungsi yang sebelumnya diikat untuk membentuk motif tertentu dan dicelupkan ke dalam zat pewarna alami. Sampai saat ini tenun troso telah berkembang menjadi sebuah industri rumah tangga yang menopang perekonomian dengan pasar yang tersebar luas di berbagai daerah di Indonesia bahkan sampai ke bebarapa negara. Kondisi yang ada, pengrajin kurang memperhatikan aspek manajemen maupun aspek konsistensi kualitas. Permasalahan yang ada di UKM mitra antara lain; 1) Kesulitan merekrut karyawan dan teknologi yang masih mengandalkan manusia; 2) Belum memiliki sistem administrasi keuangan yang baik. Solusi yang ditawarkan untuk menjawab permasalahan adalah: 1) Memodifikasi Alat Tenun Bukan Mesin (ATBM) menjadi alat tenun semi mesin (ATSM); 2) Menyusun Sistem Administrasi keungan. Tujuan dari solusi: 1) Peningkatan kualitas produk; 2) Meminimalkan ketergantungan tenaga terampil tenun dan Meningkatkan produktivitas; 3) Memudahkan pengrajin dalam menyusun dan mengontrol pekerjaan. Serta memberikan kemudahan dalam mengambil keputusan
\end{abstract}




\section{PENDAHULUAN}

UKM tenun ikat troso merupakan salah satu UKM di Kabupaten Jepara yang menyerap tenaga kerja sebanyak 5.412 orang (Badan Pusat Statistik, 2017). Tenun ikat adalah kriya tenun yang berupa kain yang ditenun dari helaian benang pakan atau benang lungsi yang sebelumnya diikat untuk membentuk motif tertentu dan dicelupkan ke dalam zat pewarna alami.

Kerajianan tenun ikat troso merupakan upaya kreatif masyarakat Desa Troso yang mengembangkan ciri khas kain ikat. Industri kreatif tenun ikat troso saat ini telah berkembang yang menopang perekonomian Desa Troso. Tenun ikat telah menjadi mata pencaharian masyarakat Desa Troso, pengrajin banyak menyerap tenaga kerja baik dari Desa Troso maupun dari Desa lain. Hal ini menunjukkan bahwa industri kreatif tenun ikat troso telah mengalami perkembangan, baik dari jumlah produksi, pemasaran, maupun ekonomi maysrakat. Pengalaman dan kemampuan yang dimiliki oleh para pengrajin telah menyebabkan kegiatan yang telah berkembang ini hingga kini mampu bartahan di desa Troso, walaupun latar belakang sosial dan pengetahuannya masih sering membatasi ruang gerak usahanya (Alamsyah, Indrahti, \& Maziyah, 2013).
Alat tenun yang dipakai adalah alat tenun bukan mesin (ATBM). Hal ini karena kain ikat troso merupakan susunan dari helaian benang pakan yang sebelumnya telah dibentuk motif dengan cara diikat dan diberi warna, sehingga untuk membuat kain ikat tukang tenun harus menyusun dan menata satu persatu helaian benang tersebut agar mendapat motif yang inginkan. Berbeda dengan kain polos tanpa harus menata motif yang diinginkan sehingga alat tenun bisa menggunakan alat tenun mesin (ATM).

Produk tenun ikat Troso memiliki banyak varian produk dengan berbagai motif dan warna, ada kain ikat airbrush, kain ikat SBY, kain ikat CSM, kain ikat 20, kain ikat selendang, taplak, kain antik, kain ikat/endek, kain baron, kain skaf. Produk-produk tersebut telah memiliki pangsa pasar yang berbeda-beda untuk dipasarkan didalam maupun luar negeri.

Produk-produk yang telah dikenal di Malaysia misalnya kain antik baik untuk selimut, bed cover, taplak, selendang, syal maupun produk turunanya yang telah dibentuk tas, gantungan tempat kertas, maupun yang lain. Sampai saat ini produkproduk tersebut masih banyak permintaan akan tetapi pengrajin telah mengalami kesulitan untuk memproduksi sesuai jumlah permintaan karena pekerja tenun 
lebih memilih untuk berkerja untuk motif kain yang lain.

Kain tenun ikat troso dibuat dari berbagai bahan baku baik dari bahan baku yang dibuat dari Indonesia maupun bahan impor dari india maupun china. Ketergantungan bahan katun dari india sangat besar oleh pengrajin tenun ikat troso, terutama untuk membuat produk kain ikat yang digunakan untuk baju dan sarung.

Proses produksi yang ada di mitra memiliki 2 cara untuk 2 kelompok jenis kain yang berbeda yaitu kelompok kain tenun ikat untuk bahan sarung, baju dan kain sejenis yang disebut dengan kain csm, dan kelompok kain syal, taplak, selimut, dan king yang disebut dengan kain antik.

Proses produksi kain csm ada dua jenis bahan yang diolah, yaitu pembuatan pakan dan pembuatan lusi. Proses pembuatan pakan ini merupakan proses yang panjang dan yang menentukan pola atau motif yang dihasilkan. Proses ini dimulai dengan dengan melakukan penyepolan benang dengan menggunakan alat sepol. Nyepol merupakan langkah awal dari bahan baku benang yang digulung pada sepulan yang akan digunakan untuk proses berikutnya yaitu ngeteng.

Ngeteng merupakan penempatan benang pada alat yang namany plangkan yang digunakan untuk menggambar pola atau motif yang diharapkan. Setelah proses gambar selesai makan akan dikerjakan dengan mengikat setiap treng atau bandel benang yang ada pada plangkan dengan mengikuti pola atau motif yang ditentukan. Setelah selesai proses ikatan maka masuk tahap berikutnya yaitu pewarnaan dasar yang dilakukan dengan proses pewarnaan kimia. Setelah didapat warna dasar yang dikehendaki maka proses selanjutnya adalah batil, batil ini merupakan proses memutuskan ikatan yang membentuk pola dengan solder sehingga tidak merusak benang yang ada, dan setelah semua selesai di putus ikatannya maka diberikan warna untuk motif yang dikehendaki. Dan proses terakhir adalah bungkar, ini adalah proses untuk bungkar benang dari yang telah selesai proses pewarnaan akhir dan memiliki diameter lingkaran cukup lebar dan disempitkan dengan menggunakan alat bungkar.

Proses Pembuatan Lusi dimulai dari pewarnaan benang sebagai dasar warna atau yang disebut menter. Proses menter ini menggunakan bahan pewarna tekstil dengan berbagai warna sesuai permintaan. Setelah proses menter (pewarnaan benang) maka akan dikeringkan dengan memanfaatkan sinar matahari langsung ataupunmenggunakan open jika kondisi 
cuaca hujan. Setelah kering maka diproses selanjutnya yaitu sepol, proses ini adalah dengan menggulung benang pada sepolan dengan alat sepol baik manual atau tradisional maupun menggunakan mesin sepol yang ada, kemudian proses selanjutnya adalah dengan memesukkan sepolan yang sudah penuh benang tersebut ke dalam mesin sekir guna diproses untuk menjadi bom yang dipakai sebagai lusi pada alat tenun bukan mesin yang ada di UKM tenun ikat torso. Proses produksi selanjutnya yaitu proses penenunan yang masih menggunakan alat tenun bukan mesin (ATBM).

Kondisi UKM menurut Soetjito Wiro Sardjono dalam Sulistiyani, (2010) memiliki ciri pola kegiatannya tidak teratur baik dalam waktu, permodalan maupun pendapatan. Kondisi tersebut terjadi hampir diseluruh UKM tenun ikat troso. Mitra pengabadian masih menggunakan sistem tradisional dimana pemilik merupakan pusat pendistribusian kegiatan dan pengelolaan usaha. Pemasaran, operasional, rekrutmen SDM dan keuangan semuanya dikelola sendiri oleh pemilik tanpa memiliki sistem administrasi perusahaan.

Penelitian Ismanto, menunjukkan bahwa kemampuan manajemen UKM memiliki pengaruh terhadap kinerja perusahaan dalam memenuhi permintaan pelanggan. Kemampuan manajemen pengrajin dapat meningkatkan efektivitas dan efisiensi waktu dan biaya sehingga dapat meningkatkan laba perusahaan yang menjadi indikator dari kinerja keuangan. Namun kondisi di mitra pengabdian (Handiqa Jaya dan Kencana Indah) masih terpusat pada pemilik dan belum memiliki catatan administrasi yang mempermudah pemilik untuk mengetahui tingkat keuntungan yang pasti. Pemilik masih mengandalkan perkiraan tentang keuntungan.Berikut permasalahan yang ada dalam UKM Mitra sebagaimana yang teridentifikasi tim pengabdi dan disepakati dengan mitra adalah sebagai berikut

1. Aspek Manajemen, UKM belum memiliki sistem administrasi maupun orang yang bekerja sebagai administrasi perusahaan. Sehingga untuk mengetahui secara tepat keuntungan usaha belum bisa, pemilik hanya memperkirakan keuntungannya. UKM ini juga belum memiliki Sistem Akuntansi, auditing, pajak, maupun pola manajemen professional.

2. Dari aspek produksi, UKM Mitra saat ini kesulitan merekrut karyawan terutama untuk produk yang memiliki prospek ekspor yaitu kain Antik yang 
terdiri dari Syal, taplak, sajadah, dan juga selimut. Permintaan pasar cukup banyak tetapi UKM tidak bisa memenuhi karena tidak adanya karyawan yang mau berkerja dalam pembuatan kain tersebut. Alasan yang banyak dikeluhkan karyawan adalah beratnya proses produksi kain tersebut. Alat yang digunakan juga masih menggunakan alat tradisional, padahal untuk jenis kain ini mesin dapat dimodifikasi dengan menerapakan mesin.

\section{METODOLOGI PELAKSANAAN}

Metode pelaksanaan program pegabdian dalam mengembangkan usaha UKM tenun ikat torso yang akan bertindak sebagai salah ujung tombak pembangunan ekonomi di masyarakat Jepara dapat dilihat pada table 1 .

Tabel 1 Macam Kegiatan Yang Diusulkan

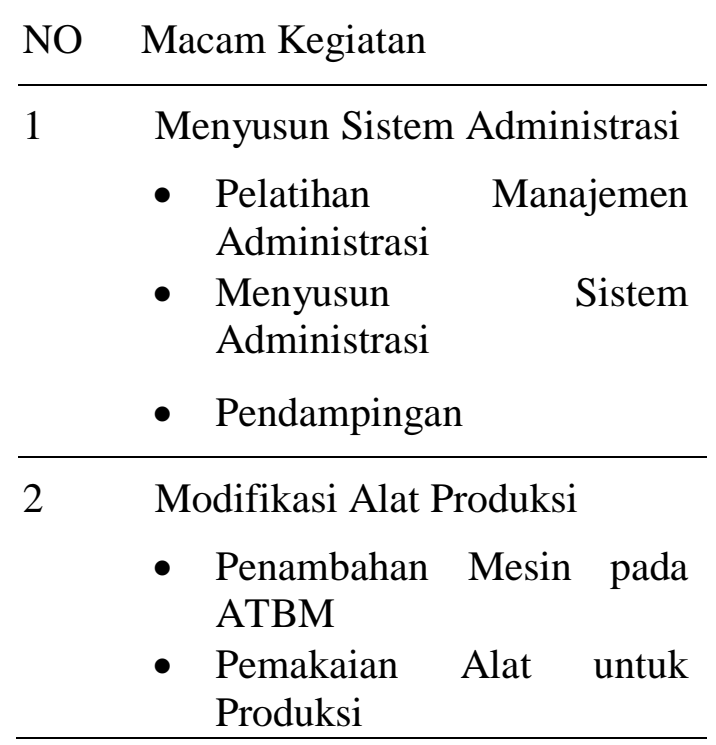

Pelaksanaan kegiatan pengabdian dilakukan dua kegiatan, yaitu menyusun sistem administrasi dan Modifikasi alat produksi.

\section{1) Menyusun Sistem Administrasi}

Dalam menyusun sistem admnistrasi terlebih dahulu dilakukan analisis situasi kerja yang ada di dua mitra UKM tenun ikat troso. Dengan melihat situasi kerja dan kondisi pekerjaan yang dilaksanakan oleh kedua mita UKM troso, maka tim akan dapat menyusun sistem adminitrasi yang cocok bagi kedua mitra UKM. Setelah melakukan analisis situasi maka tim akan melakukan pelatihan bagi kedua Mitra UKM. Pelatihan ini diharapkan akan meningkatkan pengetahuan dan pemahaman akan pentingnya administrasi bagi usaha, karena selama ini UKM belum banyak yang memiliki administrasi yang dapat mengontrol kelangsungan usaha. Setalah melakukan pelatihan dan mendapat masukan dari hasil diskusi dengan kedua mitra UMK tenun ikat troso, maka tim akan menyusun sistem adminitrasi yang cocok bagi UKM tenun ikat troso. Setelah selesai penyususnan maka sistem administrasi tersebut diserahkan dan dialakukan pendampingan agar dalam penerapan atau pelaksanaan 
sistem administrasi tersebut dalam berjalan dengan baik.

\section{2) Modifikasi Alat Produksi}

Langkah pertama yang dilakukan dalam memodifikasi alat tenun adalah dengan melakuakan Pemilihan Alat yang dapat dimodifikasi dengan menambahkan mesin pada alat tenun bukan mesin, hal ini perlu dilakukan karena akan ada penyesuaian alat dengan bahan baku yang diproduksi, sehingga perlu di setting agar hasil dari alat tersebut dapat menghasilkan kain yang berkualitas tinggi. Setelah dilakukan penambahan mesin pada ATBM maka dilakukan uji coba mesin tanpa benang, setelah dapat berjalan dengan baik, maka diilakukan penyesuaian dengan benang yang akan diproduksi, hal ini sangat menentukan berhasil atau tidaknya mesin yang akan dipakai nantinya. Untuk itu perlu adanya kemampuan setting alat yang baik guna dapat menghasilkan kain yang dapat diproduksi. Setalah alat modifikasi mesin itu dapat berjalan dengan baik, maka tahap terakhir adalah pemakaian alat untuk produksi, dengan modifikasi alat tenun bukan mesin menjadi alat tenun mesin ini, diharapkan adanya peningkatan jumlah produksi guna memnuhi kebutuhan kain dipasar, meski pada tahun pertama ditargetkan ada penambahan 50\% dari jumlah produksi saat ini. Dengan alat ini pula kesulitan mitra akan tenaga kerja untuk produk prospek ekspor ini sedikit berkurang, karena satu orang akan dapat mengoperasionalkan beberapa mesin untuk produksi.

\section{HASIL DAN PEMBAHASAN}

\section{Menyusun Sistem Administrasi}

1) Pelatihan Manajemen Administrasi Pelatihan manajemen administrasi bagi mitra diikuti perwakilan dari masing mitra sebanyak 10 orang. Yang terdiridari 4 orang dari UKM Handiqa Jaya dan 3 orang dari UKM Kencana Indah. Pelatihan ini sendiri bertujuan untuk memberikan pemahaman tentang bagaimana pengelolaan usaha yang profesional, mulai pengelolaan asset, pengelolaan keuangan, maupun pengelolaan SDM. Selain itu diberikan pemahaman pentingnya administrasi bagi perusahaan agar segala aktivitas dalam terangkum dengan pasti dalam suatu sistem. Pelatihan dilaksanakan pada hari ahad tanggal 7 Agustus 2016 yang berlokasi di UKM Handiqa Jaya.

2) Menyusun Sistem Administrasi

Dalam menyusun sistem administrasi terlebih dahulu dilakukan analisis 
situasi kerja yang ada di tiga mitra UKM tenun ikat troso. Setalah dipahami tentang pola kerja yang ada di ketiga mitra serta memperhatikan kemampuan mitra dalam menjalankan administrasinya maka tim menentukan model pencatatan berdasarkan pemasukan dan pengeluaran kas. Tim menggunakan bantu excel untuk membuat sistem pencatatan kas harian, daftar biaya tenaga kerja dan jumlah kain yang di produksi, persedian bahan baku, dan persediaan barang jadi. Empat model pencatatan yang diserahkan kepada mitra diharapkan terjadi perubahan dalam pengelolaan usaha menjadi lebih mudah dikontrol dan tidak mengalami kerugian karena kelebihan pembelian bahan baku. Gambar berikut merupakan aplikasi dengan excel yang disusun oleh tim pengabdi dan telah diserhakan kepada masing-masing mitra untuk diaplikasikan dalam menjalankan usahanya.

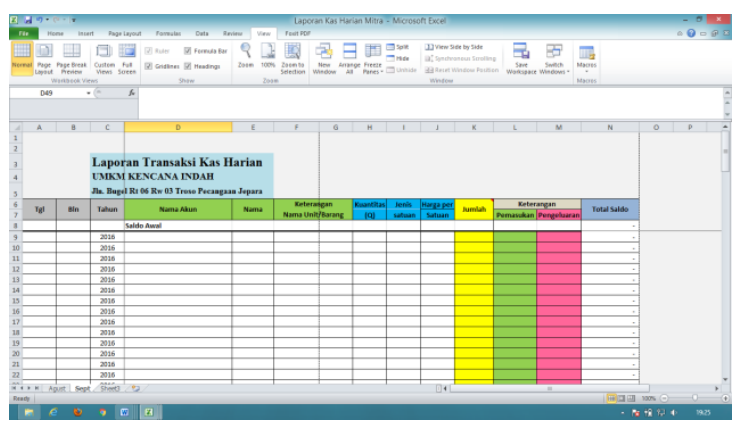

Gambar 1. Screenshoot Model Laporan Transaksi Kas harian

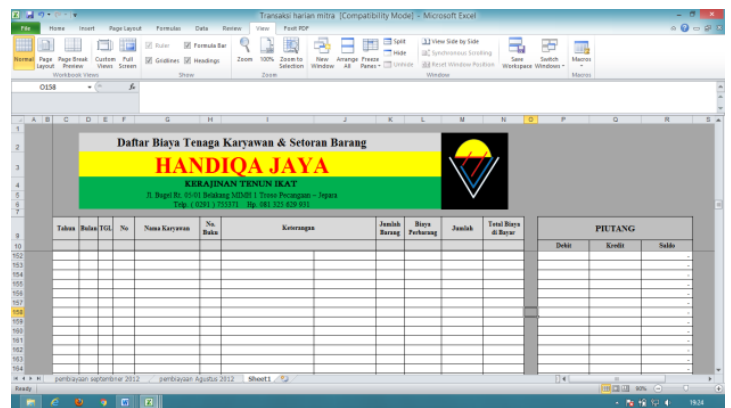

Gambar 2. Screenshoot Daftra Biaya Tenaga Kerja dan Setoran Barang

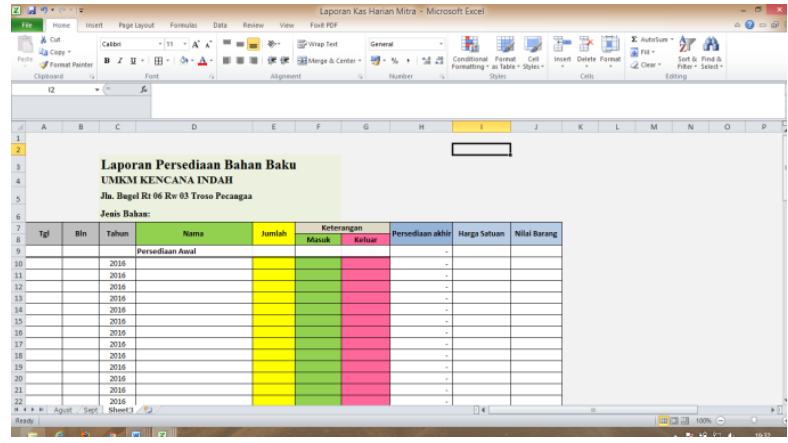

Gambar 3. Screenshoot Laporan Persediaan Bahan Baku

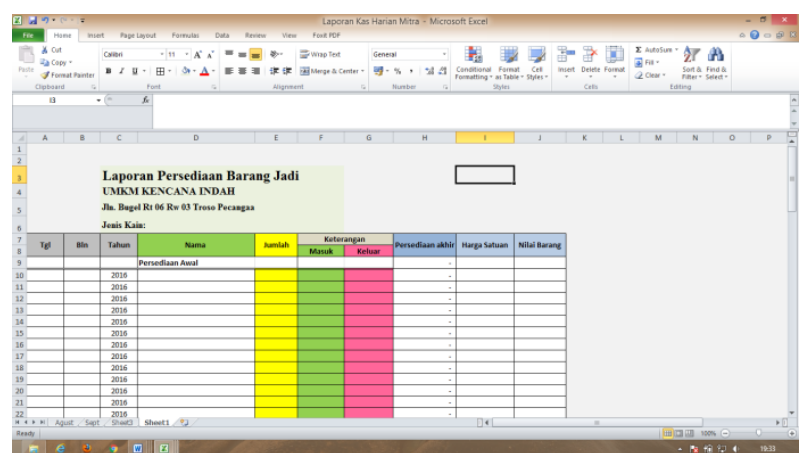

Gambar 4. Screenshoot Laporan Persediaan Barang Jadi

Pelaksanaan sistem administrasi dapat dilaksanakan dengan baik dalam laporan arus kas sebagaiman dapat dilihat pada gambar 15, akan tetapi pada aplikasi yang lain belum dilaksanakan dengan optimal, hal ini merupakan kendala bagi tim pengabdi dalam mengimplementasikan seluruh model administrasi yang telah 
disusun. Ketiga mitra mengalami kesulitan karena harus mendata seluruh kebutuhan yang diperlukan, selain itu pemilik lebih mementingkan kemudahan dalam melihat keuntungan. Pemilik sangat percaya terhadap karyawannya sehingga kurang peduli terhadap jumlah bahan baku, maupun persediaan barang jadinya. Pemilik mencatat seluruh kain yang kerjakan karyawannya, dengan pencatatan yang mampu telusur artinya dicatat mulai dari nama karyawan, jumlahnya, dan diberikan tanda pada kain yang dipotong untuk mengontrol kualitas yang diproduksi.

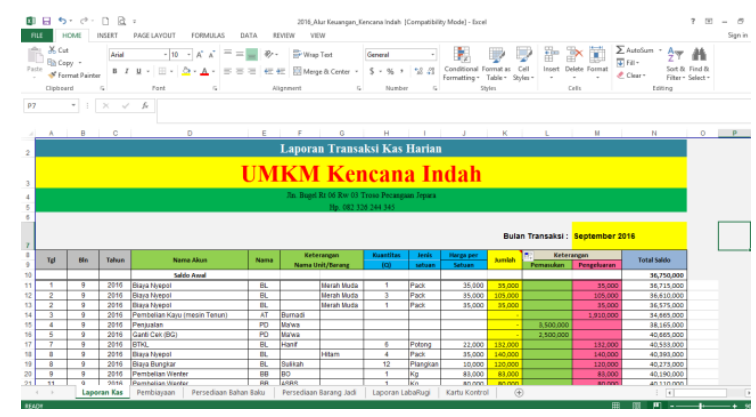

Gambar 5. Screenshoot Laporan Arus Kas Bulan September

\section{3) Pendampingan}

Pendampingan dilakukan oleh tim untuk memastikan seluruh kegiatan yang dirancang dapat berjalan dengan baik. Dengan pendampingan yang dilakukan oleh tim pengabdi, pemilik merasa terbantu dalam melaksanakan sistem administrasidan juga dalam menjalankan alat tenun semi mesin yang diserahkan. Hal ini karena pemilik masih memerlukan penjelasan dalam menjalankan sistem administrasi. Kendala yang ada adalah kosistensi dalam mendata seluruh kegiatan perusahaan. Tim pengabdi selalu memantau perkembangan penggunaan aplikasi tersebut guna membangun budaya kerja yang lebih terdata.

\section{Modifikasi Alat Produksi}

Tim bekerjasama dengan ahli pembuat alat tenun bukan mesin (ATBM) memodifikasi dengan penambahan dinamo sebagai alat penggerak alat tenun. Sampai laporan ini dibuat alat tersebut masih tahap perakitan. Setelah alat tenun bukan mesin dimodifikasi maka akan diserahkan pada mitra untuk dapat digunakan dalam menambah kapasitas produksi. ATBM hasil modifikasi dapat memproduksi 2 kali lebih cepat dari pada produksi menggunakan tenaga manusia yang selama ini masih diandalkan oleh mitra.

Modifikasi alat tenun bukan mesin yang dijadikan semi mesin ini menyesuaikan dengan kebutuhan kain yang akan diproduksi. Hal ini dibutuhkan agar penggunaan dinamo penggerak lebih sesuai dengan kebutuhan 


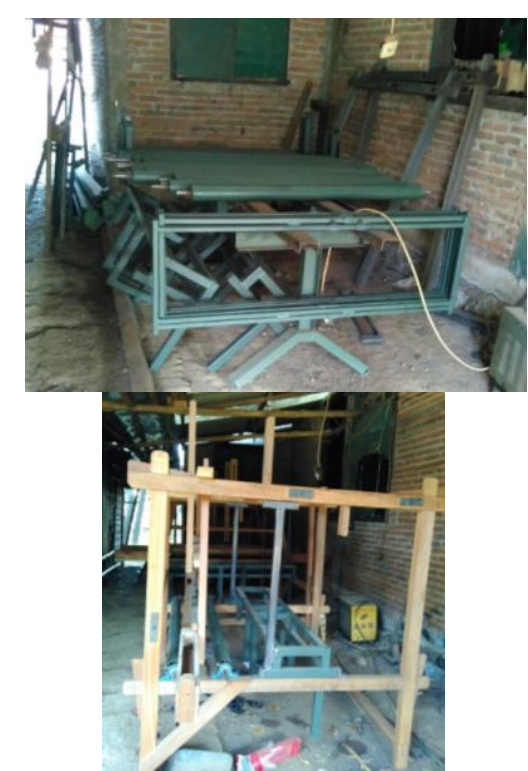

Gambar 6. Bagian Alat Tenun Bukan Mesin yang dimodifikasi

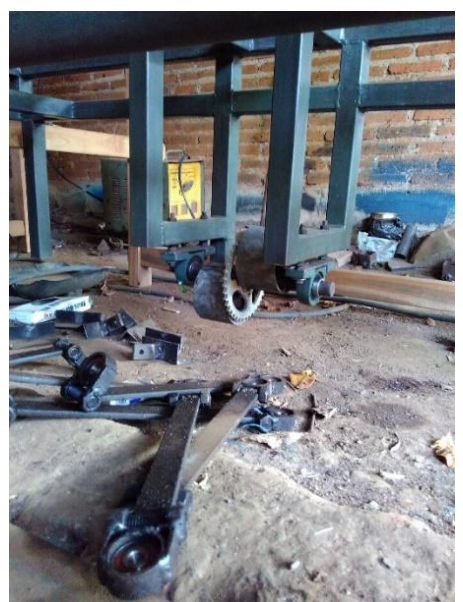

Gambar 7. Kompenen Penggerak Kamprah (Penganam Benang)

Penambahan alat dengan menggunakan beberapa komponen tambahan yang memjadikan alat tenun bukan mesin menjadi alat tenun semi mesin. Alat ini dpat dioperasikan oleh satu orang yang memegang 2 mesin. Tingkat produksi dari alat semi mesin ini lebih cepat dibandingkan dengan alat tenun bukan mesin yang mengandalkan tenaga manusia dengan perbandingan $1: 1,5$ potong ( 1 potong dengan ATBM; 1 potong alat semi mesin).

\section{KESIMPULAN}

Dari Hasil pelaksanaan Pengabdian

Ipteks bagi Produk Ekspor yang

diselenggarakan dapat disimpulkan:

1. Program penyusunan sistem adminitrasi telah berjalan dengan baik, terbukti dengan sudah selesainya penyusunan sistem adminitrasi dengan menggunakan excel.

2. Program Pelatihan Adminitrasi telah terlaksana dengan memberikan pemahaman pemilik bahwa administrasi UKM dapat mendukung berjalannya UKM menjadi lebih baik.

3. Program peberian alat tenun semi mesin hasil modifikasi dari alat tenun bukan mesin telah terlaksana dengan baik, dengan ditunjukkan adanya peningkatan produktivitas hasil kerja.

\section{SARAN}

Agar Implementasi dari ipteks bagi Produk Ekspor yang telah di buat bisa bermanfaat dengan baik, maka:

1. Output yang dihasilkan dari adminitrasi harus selalu menjadi bahan masukan bagi pengambilan keputusan bagi pemilik Usaha.

2. Sistem administrasi yang telah diberikan agardapat dijalankan dengan 
baik dalam membantu pengelolaan usaha mitra.

\section{UCAPAN TERIMAKASIH}

Kami menyampaikan terima kasih kepada semua pihak yang telah bekerjasama dan membantu pelaksanaan program pengabdian ini, terutama ditujukan kepada:

1. Kementerian Riset, Teknologi, dan Pendidikan Tinggi, Direktorat Jenderal Penguatan Riset Dan Pengembangan Direktorat Riset dan Pengabdian Masyarakat yang telah mendanai pelaksanaan program Pengabdian ini.

2. Kopertis Wilayah VI Jawa tengah yang telah mengkoordinir dan memfasilitasi pelaksanaan pengabdian kepada masyarakat ini.

3. Lembaga Penelitian dan Pengabdian kepada Masyarakat UNISNU Jepara yang telah mengkoordinir terlaksananya kegiaatan pengabdian ini.

4. Mitra kami UKM Tenun Ikat Handiqa Jaya dan Kencana Indah yang telah bersedia untuk menjadi mitra dalam prlaksanaan program Pengabdian ini.
POTRET KEWIRAUSAHAAN PADA

MASYARAKAT DESA (1st ed.).

Semarang: CV Madina.

Badan Pusat Statistik. (2017). Banyaknya Unit Usaha (unit) dan Tenaga Kerja (orang) Dirinci Menurut Jenis Industri Kecil Menengah di Kabupaten Jepara (IKM), 2015. Retrieved from https://jeparakab.bps.go.id/linkTabelS tatis/view/id/489

Ismanto, H. (2016). Analisis Kinerja Keuangan UMKM Tenun Ikat Troso Jepara. Jurnal Economia, 12(2), 159166.

Sulistiyani. (2010). Pengaruh Kemampuan Manajerial Kreativitas Program Pemasaran Dan Kemampuan Berinovasi Terhadap Kinerja Usaha Kecil dan Menengah. Economica, 1(1), 89-100.

\section{REFERENSI}

Alamsyah, Indrahti, S., \& Maziyah, S.

(2013). KEARIFAN LOKAL PADA

INDUSTRI TENUN TROSO: 